\title{
CINE EN CLAVE DE TEORÍA CRÍTICA: LA PELÍCULA COLOMBIANA YO SOY OTRO Y SU LECTURA DEL CONFLICTO ARMADO $^{1}$
}

Por:

Manuel Silva Rodríguez

Profesor Escuela de Comunicación Social

Universidad del Valle

manuel.silva@correounivalle.edu.co

\section{CINEMA ON KEY OF CRITICAL THEORY: COLOMBIAN FILM "YO SOY OTRO" AND HIS READING OF ARMED CONFLICT}

Resumen: Este artículo establece una relación entre el largometraje colombiano Yo soy otro (2008) y algunas ideas elaboradas por Theodor Adorno y otros filósofos con tesis próximas al pensamiento del filósofo alemán. El texto pone el énfasis en la nociones de dialéctica y de no identidad y expone la manera como en el filme estas categorías adquieren una dimensión política asociada al conflicto armado en Colombia.

Palabras Clave: Dialéctica Negativa, Cine Colombiano, Conflicto Armado en Colombia, Ensayo Audiovisual, Teoría Crítica.

Abstract: The article establishes a relationship between the Colombian film"Yo soy otro" (2008) and some ideas developed by Theodor Adorno and other philosophers whose tesis are similar to the german philosopher. The text emphasizes the notions of dialectic and no identity and exposes how these categories in the film take a political dimension associated with armed conflict in Colombia.

Keywords: Negative Dialectics, Colombian Cinema, Armed Conflict in Colombia, Audiovisual Essay, Critical Theory. 


\section{Introducción}

Este texto propone examinar una relación posible entre el largometraje colombiano contemporáneo Yo soy otro (Óscar Campo, 2008) y algunas ideas vinculadas a la Teoría crítica de la sociedad (TC) o susceptibles de ser adscritas a esa línea de pensamiento social y filosófico. La premisa aquí no es qué nos dice la TC sobre el cine, como se puede apreciar por ejemplo en la producción de Walter Benjamin o de Theodor Adorno, sino cómo en el cine - para el caso un filme en particular - podemos ver algunas ideas asociadas a la TC - y por extensión al pensamiento crítico.

Ahora bien, la elección de la película de Óscar Campo se hace por la manera como en este filme forma y contenido se implican para formular, a mi juicio, un texto próximo al ensayo audiovisual. Un texto fílmico que, aunque no exento de algunos excesos retóricos y discursivos, propone una reflexión más de orden conceptual que narrativa sobre el conflicto armado en Colombia a comienzos del siglo XXI.

En este orden de ideas, este artículo busca señalar cómo Yo soy otro encarna una discusión en la esfera de lo político de la dialéctica entre la singularidad y la totalidad, por lo cual considero que el filme pone en imágenes algunos presupuestos de la filosofía de Adorno, de Roberto Esposito y de Jacques Ranciére, sin que sus planteamientos se agoten en relacionarlos con estos nombres.

\section{Cuestiones de forma}
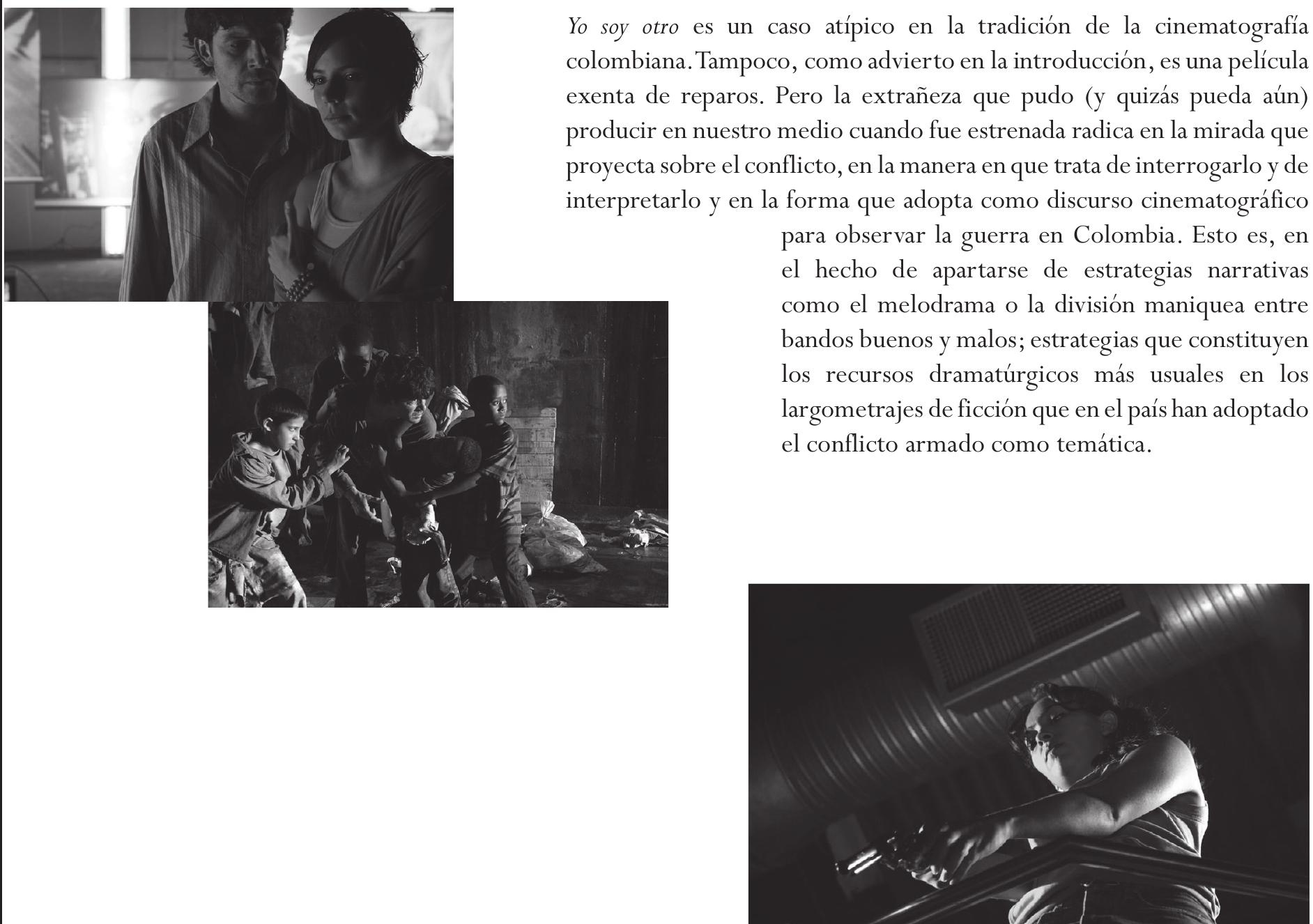
La película gira alrededor de una compleja trama que transcurre en la ciudad de Cali en un momento histórico preciso: luego de los atentados terroristas del $11 \mathrm{de}$ septiembre del 2001 en Estados Unidos y tras la ruptura, en febrero de 2002, de los diálogos de paz entre el gobierno de Andrés Pastrana y las Farc. Es decir, desde su comienzo, como en una suerte de premisa argumentativa Yo soy otro yuxtapone dos fenómenos de violencia contemporánea y hace visible con esta asociación una doble manifestación, en los planos nacional e internacional, del orden global: el espacio político en tiempos del capitalismo avanzado aparece desvelado como escenario de contienda bélica. En ese marco histórico y cultural, el filme presenta la historia de José, un burgués citadino y consumista atrapado entre las fuerzas ideológicas que pugnan por colonizar el espacio intersubjetivo.

En un plano narrativo y formal, para formular y desarrollar sus planteamientos Yo soy otro se vale de convenciones provenientes de tradiciones como la ciencia ficción, la literatura fantástica, el relato autobiográfico, el collage y el palimpsesto. A este rasgo se suma la conjunción de imágenes producidas dentro de los códigos del cine de ficción — en no pocos casos con referencias a filmes emblemáticos — con imágenes codificadas en las esferas del documental y del archivo. A esta mezcla, además, como lo expongo aquí, se agrega una variedad de ideas rastreables en la filosofía contemporánea. Esta mixtura de códigos reviste a Yo soy otro de un aire de dispersión narrativa, formal y discursiva, de cierta indefinición deliberada en su sistema de representación. Siguiendo a Arlindo Machado, y de manera similar a como ocurre por ejemplo con La Jeteé de Chris Marker (1962), es notorio que estas características hacen que el filme desborde de los límites del fantástico y de la ciencia ficción y se sitúe cerca de la esfera del ensayo:

Pensemos el film ensayo hoy. Puede ser hecho con cualquier tipo de imagen-fuente: imágenes captadas por cámaras, diseñadas o generadas en una computadora, además de textos obtenidos mediante generadores de caracteres, gráficos y también toda clase de materiales sonoros. Es por eso que el filme-ensayo supera largamente los límites del documental. Incluso puede usar escenas de ficción, tomadas en estudios con actores, porque su verdad no depende de ningún "registro" inmaculado de lo real, sino de un proceso de búsqueda e indagación conceptual. (Machado, 2012, p. 188)

Ahora bien, si en un nivel superficial observamos claramente que la película transcurre en un tiempo y un espacio reconocibles, los recursos narrativos de los que también se sirve permiten al filme situarse en un espacio interior y subjetivo. Es decir, actúan como dispositivo para, a través de imágenes, de acciones y, a veces con un exceso innecesario, de palabras, representar la guerra ideológica y la instrumentalización política del lenguaje que en Colombia se han tomado la esfera social y, por extensión, las conciencias. 


\section{La ambición de los universales}

Yo soy otro puede ser leída como una construcción cinematográfica de la imposibilidad de una síntesis dialéctica. En particular, como la imposibilidad de una síntesis dialéctica en términos políticos a la luz de la situación del conflicto armado en Colombia en la primera década del siglo XXI.Y es al interpretarla así, principalmente, donde esta película se encuentra con algunos conceptos fundamentales del pensamiento de Adorno. Y no sólo de Adorno, sino también de Jacques Rancière, un filósofo muy afín en algunos puntos a ciertas ideas asociadas a la TC, y de Roberto Esposito, entre otros.

Debajo de su traje de cine fantástico, de ciencia ficción y de ciertas concesiones narrativas casi inevitables por encuadrarse también en la estructura de un relato, a través de sus figuras retóricas y de su montaje la película pone en escena la tensión y la explosión desencadenadas por el encuentro de fuerzas ideológicas irreconciliables, fuerzas que ocupan el espacio intersubjetivo y que luchan por apropiarse de toda subjetividad. Así lo expusieron Adorno y Horkheimer a mediados del siglo XX cuando advirtieron cómo totalitarismos de derecha y de izquierda buscaban subsumir toda subjetividad: "A través de la mediación de la sociedad total, que invade todas las relaciones y todos los impulsos, los hombres son reducidos de nuevo a aquello contra lo cual se había vuelto la ley de desarrollo de la sociedad, el principio del sí mismo: a simples seres genéricos, iguales entre sí por el aislamiento en la colectividad coactivamente dirigida" (Horkheimer \& Adorno, 1998, p. 89). La crítica de los de Frankfurt a la Ilustración, a la cual desnudaron como mito y como proceso totalitario que culmina en la subsunción de lo particular y en la negación de lo extraño al sistema, en esta película la encontramos puesta al día en una representación de la disputa por la definición de lo verdadero, lo válido y, por lo tanto, lo dominante en el orden político colombiano.

En efecto, el personaje José y su conciencia son alegorías en las cuales podemos leer el cuerpo social, el espacio de intersubjetividad del cual hacemos parte y la esfera pública en la cual los discursos, apoyados no sólo en el lenguaje si no también en las armas, se disputan la hegemonía. Cuerpo y subjetividad devienen el lugar donde se libran batallas lingüísticas, ideológicas y físicas. Cuerpo y subjetividad son también los lugares donde se produce una escritura cinematográfica que desvela el choque de fuerzas, la violencia que ellas producen y, en lo que hallo la principal afinidad de esta postura con la filosofía de Adorno, la expresión de la necesidad de que lo singular no se reconcilie ni sea subsumido por lo general. 
Yo soy otro es una película comparable con lo que en los estudios literarios se llama novela de ideas. Esas novelas en las cuales los personajes y las acciones aparecen un poco desdibujados para poner en escena ideas que analizan y problematizan conceptualmente situaciones de distinta índole. Pensemos en Voltaire, Flaubert, Musil, Man, Borges, Vila Matas o Germán Espinosa para hacernos una idea. En estos autores encontramos obras en las cuales lo narrativo se diluye en lo ensayístico. Cándido, Bouvard y Pécuchet, El hombre sin atributos, La montaña mágica o El signo del pez, por citar algunos títulos, son novelas-ensayos con las cuales este filme se emparenta. En la línea de esa tradición, en esta película los recursos del doble, de la clonación y los excesivos — en ocasiones chocantes por su didactismo - comentarios de la voz en off del protagonista actúan como medio para que el cuerpo y la subjetividad sean el lugar de una pugna entre fuerzas exteriores a los individuos y de la cooptación de cada sujeto particular.
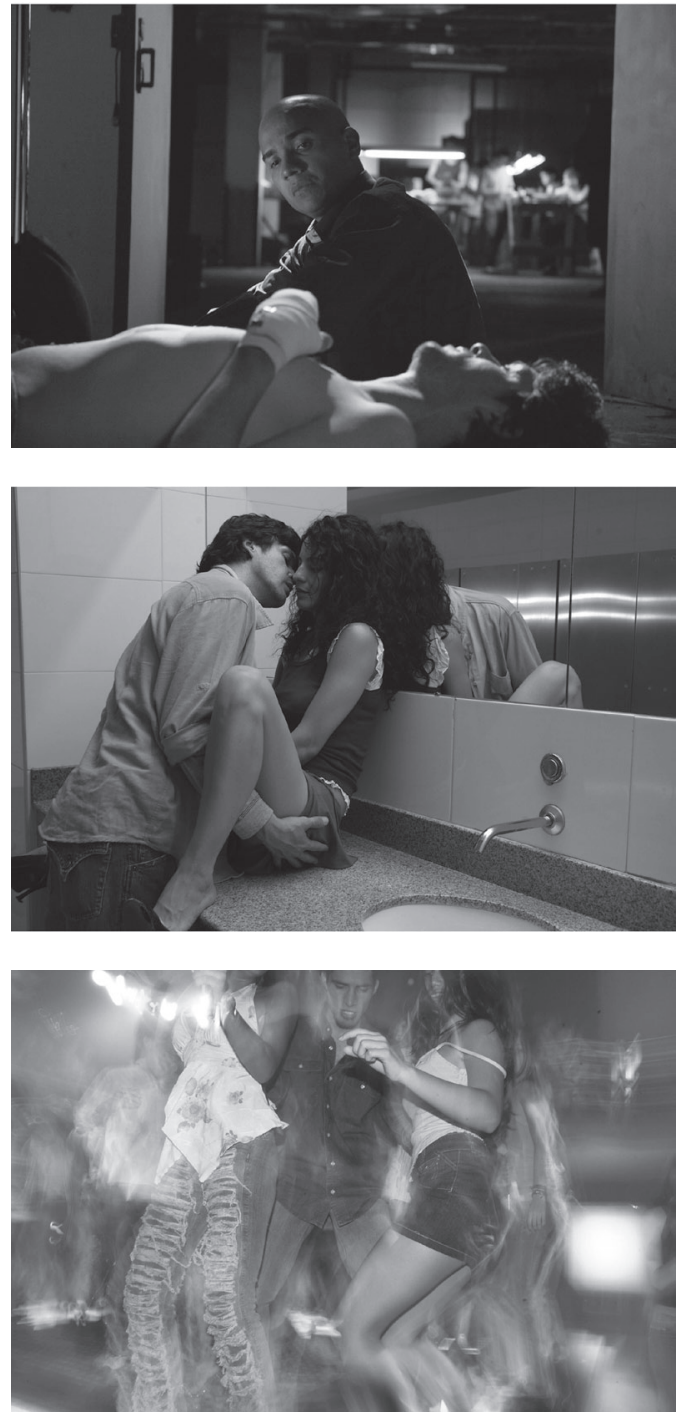

El recurso del doble, introducido en la trama a través del delirio desatado por la enfermedad y el consumo de drogas, permite que la apariencia y la personalidad de José se tornen múltiples. Esta estrategia dramatúrgica y narrativa da lugar a una subjetividad escindida, a un conflicto interior múltiple y a un cuerpo clonado. La escisión de la subjetividad, en una suerte de mitosis cancerígena, posibilita construir una conciencia convertida en territorio de pugnas. En esa conciencia fragmentada por los diversos clones cada clon busca imponer como la razón única y verdadera la propia. Ocurre dentro de ella lo queAdorno vislumbró en el proceso de la Ilustración: "Lo que no se doblega al criterio del cálculo es sospechoso para la Ilustración. Y cuando ésta puede desarrollarse sin perturbaciones de coacción externa, entonces no existe ya contención alguna [...]. Ante cada resistencia espiritual que encuentra, su fuerza no hace sino aumentar" (Horkheimer \& Adorno, 1998, p. 62). La virulencia del concepto, revelada por Adorno en los órdenes gnoseológico y social, que sólo reconoce lo idéntico a sí mismo; la violencia que el pensamiento ejerce sobre lo no-idéntico al forzar la identificación del objeto con el concepto; y el reinado de lo igual en el plano cultural que Adorno vislumbró en la sociedad mediática y de consumo con la industria cultural, son líneas filosóficas que esta película expone en el plano de la subjetividad del personaje y del espacio intersubjetivo que José habita y lo determina. 

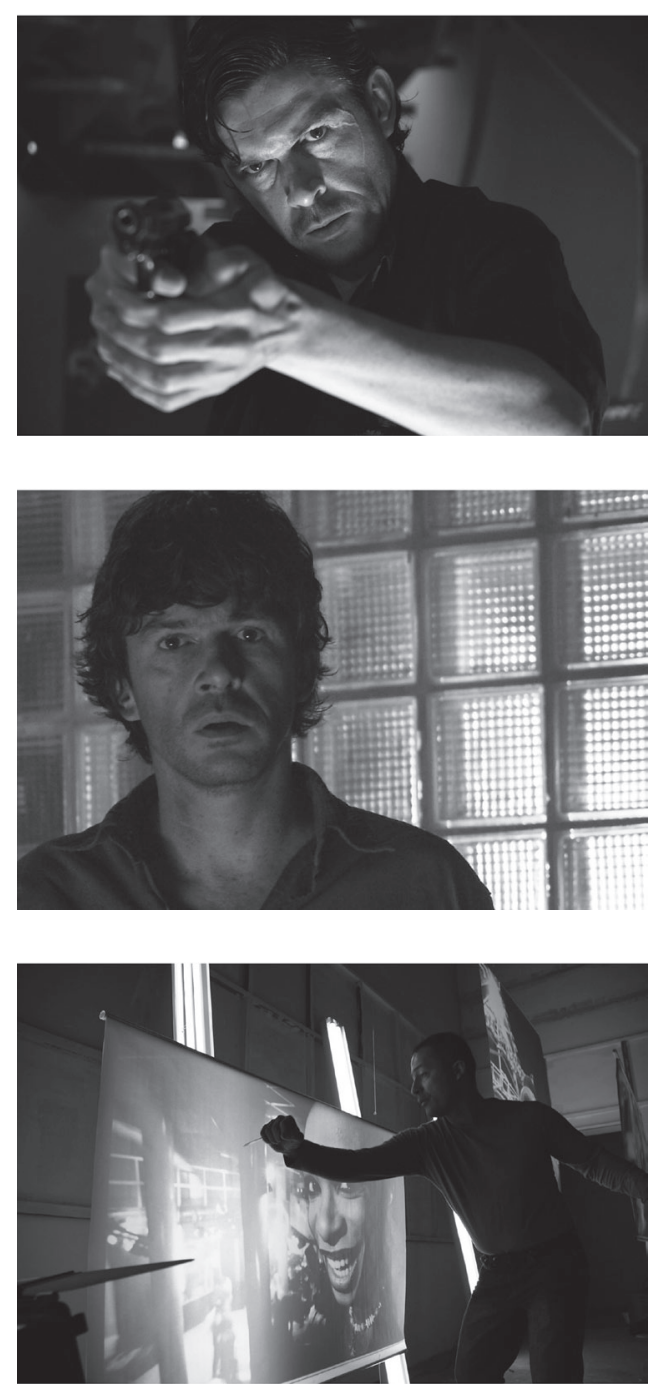

En efecto, la conciencia individual es el objeto al cual el concepto - transfigurado en forma de opinión pública, de valores de grupo social, de tendencias colectivas, finalmente de ideologíabusca subsumir. Para el caso, la conciencia individual es José, inserto en un espacio intersubjetivo caótico y desgarrado por las fuerzas que libran la guerra - guerrilla, paramilitares, Estado, la mentalidad de la vida burguesa. Son las fuerzas que se disputan el dominio del espacio físico, político y simbólico. Cada una de ellas aparece aferrada al principio de identidad, posicionada en la pretensión de ser la única, de proteger y garantizar su idea de organización colectiva $y$, supuestamente, de salvaguardar la existencia de cada individuo. Inamovible en su posición, cada fuerza niega a los individuos cualquier posibilidad de situarse fuera de las pretensiones de ella. Puesto en los términos de nuestra historia reciente, esta visión del mundo contemporáneo es un conflicto que Adorno observó:

La ratio, que con tal de imponerse como sistema eliminaba virtualmente todas las concreciones cualitativas a que se refería, cayó en una contradicción irremediable con la objetividad, a la que violentaba a pesar de darse aires de comprenderla. Tanto más se alejó de ella cuanto más perfectamente la sometió a sus axiomas, al axioma único en último término: el de la identidad (Adorno, 1975, pp. 29-30).

Por esta vía, pues, la película propone una visión actualizada en nuestro contexto histórico de uno de los motores del pensamiento de Adorno trasladados a una dimensión política.Y si bien Adorno no formuló explícitamente una teoría política, como lo han mostrado varios autores, no se puede afirmar que por ello no exista un alcance político o una faceta política de su pensamiento ${ }^{2}$. En mi opinión, una forma de presentarse este alcance tiene que ver con la transposición desde el plano gnoseológico al social de su reflexión sobre lo no idéntico y el impulso identificante e irreflexivo del pensamiento sistemático. El mismo Adorno estableció esta conexión de manera explícita: "Lo que queda del Idealismo es que la determinante objetiva del espíritu — la sociedad — se compone tanto de la suma de los sujetos como de su negación. Los sujetos están en ella irreconocibles, inermes” (Adorno, 1975, p. 19). 
Adorno defendió la irreductibilidad de lo particular ante lo general. Según él, en lo particular siempre hay algo que escapa, que no se deja atrapar por el concepto y por la aspiración de éste a lo universal. Ese principio de lo otro irreductible lo opuso al concepto: "El objeto solo puede ser pensado por medio del sujeto; pero se mantiene siempre frente a éste como otro" (Adorno, 1975, p. 185). Es decir, ese principio funda una dialéctica en la cual Adorno no ve ni identidad ni síntesis última universal y particular entre sujeto pensante y objeto pensado. Recordemos cómo, antes de exponerla en su sentido negativo, Adorno describe la dialéctica en Dialéctica negativa: "El nombre de dialéctica comienza diciendo sólo que los objetos son más que su concepto, que contradicen la norma tradicional de la adaequatio. [...] Dialéctica es la conciencia consecuente de la diferencia” (Adorno, 1975, p. 13).Y más adelante: "La dialéctica desarrolla la diferencia que dicta lo universal entre él y lo particular. Dialéctica es el desgarrón entre sujeto y objeto” (1975, pp. 14-15).

Expuesta así, la pretensión de lo general de ajustar dentro de su marco a lo particular fue leída como aspiración totalitaria. Llevado a términos históricos y políticos la concreción de esa tendencia fue lo que Adorno vio en el nazismo, el estalinismo y la sociedad de consumo en el capitalismo avanzado. Parte de la dimensión política del pensamiento de Adorno, por lo tanto, la localizo en la posibilidad y en el derecho de lo particular a no plegarse en el plano social a ninguna corriente con pretensiones de validez universal y absoluta, de negación de la diferencia y de persecución de lo diferente con respecto a los intereses del cálculo y del dominio. La dialéctica negativa concebida por Adorno opone, entonces, lo particular a lo general, el objeto al sistema conceptual. Es decir, defiende y reclama la condición de la singularidad de no subsumirse ante ningún universal, de negarse a su reducción: "La filosofía tiene que perder la esperanza de la totalidad: el carácter fundamental de cualquier concepto abstracto se desploma ante el ente concreto" (1975, pp. 140-141).

\section{Una visión dialéctica}

La actualización de este pensamiento en nuestro medio, entonces, la veo en el modo como esta dialéctica es presentada en la película con referencia al conflicto armado. En el filme los espacios de la subjetividad de José y de la intersubjetividad son el terreno que varios universales se disputan y buscan subsumir para dominar de manera absoluta. Estos universales son doctrinas y formaciones sociales que niegan cualquier posibilidad de situarse por fuera de ellas. Tales universales son en principio construcciones discursivas que configuran sistemas de ordenación del mundo cerrados sobre sí mismos. Se trata, en última instancia, de la representación de una misma forma de racionalidad que, a pesar de los distintos atuendos sociales que puede adoptar, en Yo soy otro se 
desnuda finalmente como la misma: en las ideologías de la guerrilla, los paramilitares, los representantes de la institucionalidad y la conciencia burguesa plegada al orden de su conveniencia inmediata.

En ese espacio de combate cada uno de estos universales intenta, primero, seducir por medio de malabares retóricos al particular, es decir a la conciencia de José.Y cuando no lo logran a través del discurso, lo que en principio es solo construcción lingüística se manifiesta posteriormente en su expresión brutal a través del terror y del sometimiento físico. Parte de lo que hace especial a esta película es que, con la mediación de la pirotecnia y la artificiosidad características del cine fantástico y de la ciencia ficción, consigue reconstruir con un argumento denso y con imágenes oníricas y documentales el campo de batalla en el cual consiste la intersubjetividad colombiana contemporánea.

La subjetividad de José, como la de cualquier colombiano fuera de la ficción, es presa de caza.

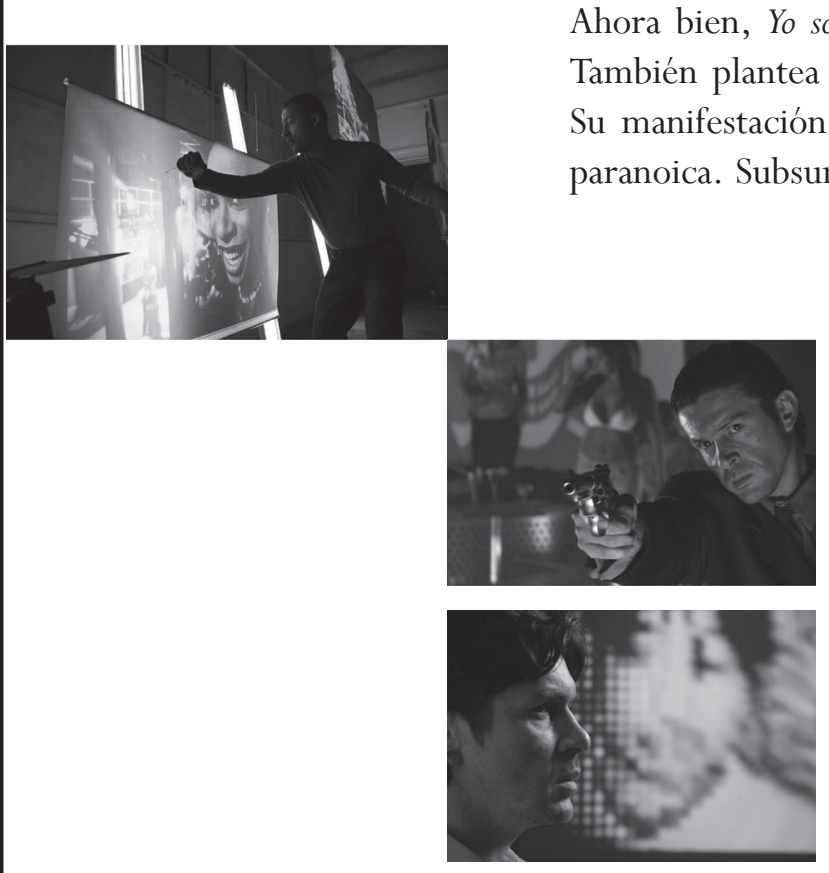

En la película cada fuerza, durante un momento específico, determina la subjetividad de José. Por eso el rostro y el cuerpo del personaje, en su mero aparecer encarnado por el mismo actor, se ven duplicados, clonados al infinito en un juego de espejos, para mostrar una misma corporalidad que no se reconoce cuando se mira en los espejos de las distintas ideologías. Es ahí donde las estrategias narrativas del doble y de la clonación hacen que la subjetividad y el cuerpo de José se multipliquen, en un delirio en el cual el interior del personaje es al mismo tiempo varios sujetos en pugna por reconocerse como uno solo. Esta multiplicación de fuerzas enfrentadas a muerte, sin voluntad para aceptar y reconocer la diferencia, conduce a la autodestrucción del sujeto individual y colectivo, al fracaso de la racionalidad que las gobierna. La subjetividad esquizoide y autodestructiva de José surge entonces 

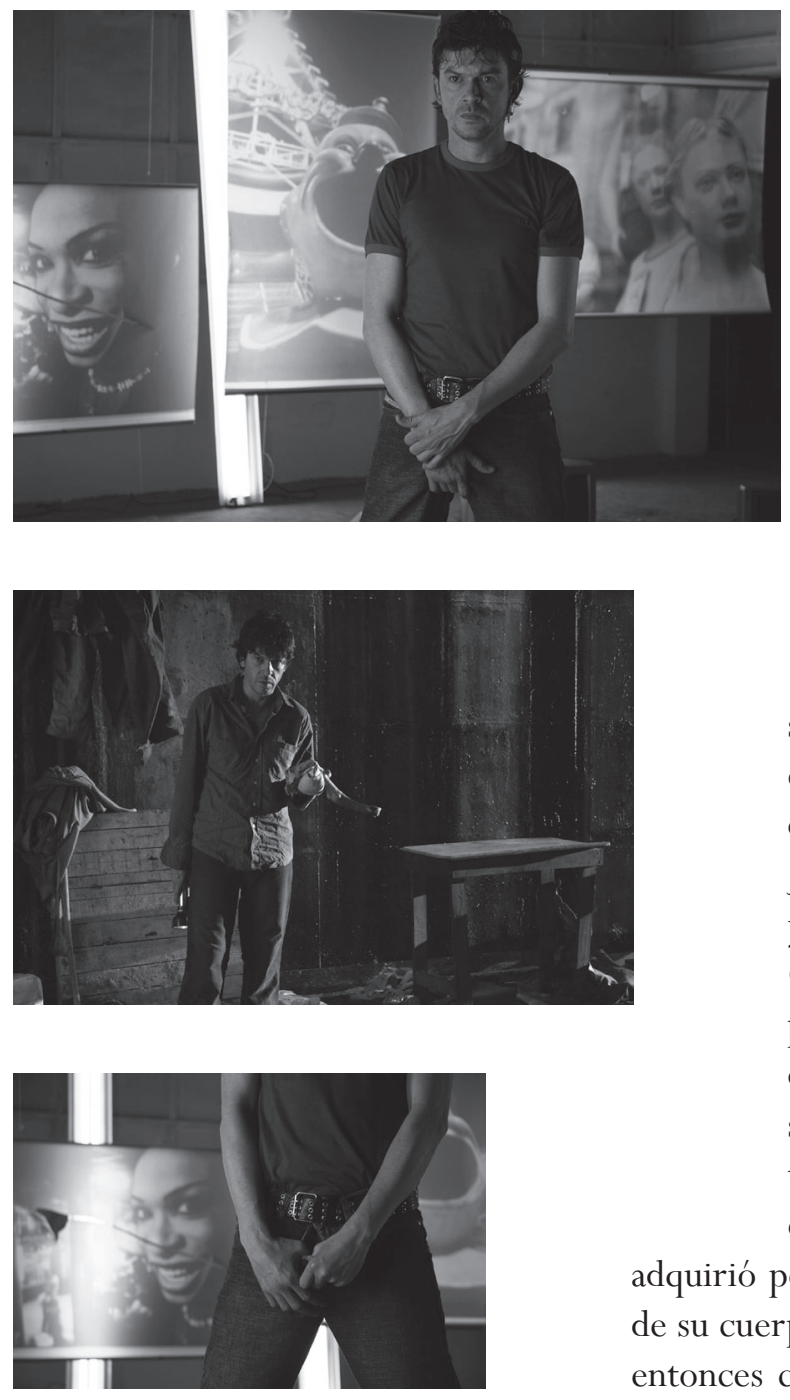

172

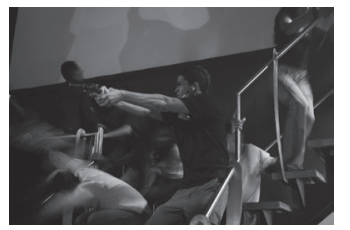

como alegoría de la intersubjetividad desplegada en el campo social. Esto es, como pusieron en evidencia Adorno y Horkheimer, el sujeto vuelto contra sí, reducido a objeto por su propia racionalidad: "La abstracción, el instrumento de la Ilustración, se comporta respecto de sus objetos como el destino cuyo concepto elimina: como liquidación" (Horkheimer \& Adorno, 1998, p. 68).

En este punto la representación del cuerpo cobra su mayor sentido. La fragmentación de la subjetividad, que se refleja en la multiplicación de lo mismo y en la negación de lo otro, se significa también a través de la multiplicación del cuerpo de José: corporalidad cooptada por cada una de las fuerzas que colonizan la subjetivad. Cada clon de José, por lo tanto, es un universal que intenta seducirlo $\mathrm{y}$, ante su resistencia, posteriormente eliminarlo. Con su mismo rostro y su mismo cuerpo, a José lo persiguen paramilitares, guerrilleros y representantes del orden social y económico. El tour de force visual se asienta en un verosímil narrativo constituido por una enfermedad infecciosa y viral. La enfermedad es de origen incierto, el personaje no sabe cómo la adquirió pero la situación concreta es que ella se ha apoderado de su cuerpo. La racionalidad común a cada fuerza es presentada entonces como un virus que invade la conciencia, el cuerpo y la sociedad. Y esta racionalidad es compartida, a pesar de las diferencias de clase social o de ubicación ideológica de quienes la ostentan, porque todas las fuerzas exponen justificaciones y comportamientos similares. Detrás de cada una de ellas subyacen el control y el poder como finalidad. Cada una se autorepresenta, para decirlo con Freud, como el principio de realidad: "El dominio se enfrenta al individuo singular como lo universal, como la razón en la realidad" (Horkheimer \& Adorno, 1998, p. 76).

Esta conciencia enferma es encarnada narrativamente por una voz que, desde un presente que evoca, a través de un monólogo intenta reorganizar el sentido de la dispersión identitaria experimentada por el personaje. Dispersión que es congruente con el coctel de convenciones cinematográficas y narrativas y con el carácter ensayístico de la película. El acto de recordar mediante la toma de una aparente distancia con respecto a los hechos recordados, entonces, se constituye en el filme en una estrategia para intentar ordenar el caos experimentado en la subjetividad. 
Junto a la conciencia el cuerpo individual surge, pues, como alegoría del cuerpo social. El cuerpo social es también un cuerpo enfermo, infecto por el virus que se extiende y determina la totalidad. Por este camino la pregunta por la identidad política individual trasciende al ámbito colectivo. En tanto universal, cada fuerza se posiciona como único agente posible de racionalidad política. Es decir, solo se habla una lengua y se figura el orden colectivo con esa misma lengua. Otro lenguaje, otra manera de entender la experiencia no son posibles. Hay allí una crítica a la posibilidad de la existencia de la comunidad política. ¿Cómo entender esta comunidad? ¿Solo como homogeneidad discursiva? ¿Como consenso? Es inocultable el diálogo que el pensamiento de Adorno, y con éste Yo soy otro, establece con la problematización del concepto de comunidad política que en tiempos más recientes elabora Roberto Esposito. En efecto, en Yo soy otro la única comunidad que pretenden fundar los universales es, como lo indica Adorno, la de la homogeneidad, la de la destrucción de la diferencia. Es decir, la comunidad no surge de la apertura, de la comunicación o de la comunión, sino del ensimismamiento, de la cerrazón, de la negación de lo externo y de la repetición de lo mismo. Dice Esposito:

Digamos que la inmunidad, o, en su formulación latina, la immunitas, resulta el contrario, el reverso, de la communitas. Ambos vocablos derivan del término munus —que significa «don», «deber», «obligación»-, pero uno de ellos, la communitas, lo hace en sentido afirmativo, mientras que el otro, la immunitas, en sentido negativo. Es por ello por lo que, si los miembros de la comunidad se caracterizan por esta obligación de donación, por esta ley de cuidado frente al otro, la inmunidad implica, en cambio, la exención o la derogación de tales condiciones (Esposito, 2009, p. 111).

En este orden de ideas, al igual que unas formas de subjetividad se hacen indeseables unos cuerpos se tornan prescindibles. Ya Adorno lo había advertido en su momento histórico: la inadecuación del objeto al concepto se experimenta corporalmente como sufrimiento, como reducción de los cuerpos al orden social y político: "La componente somática recuerda al conocimiento que el dolor no debe ser, que debe cambiar"; "Auschwitz confirma la teoría filosófica que equipara la pura identidad con la muerte” (Adorno, 1975, p. 204, 362). Esto es, y hacia allá apunta la película, se configura una forma de biopolítica en la cual unos cuerpos deciden, parafraseando a Judith Butler, cuáles cuerpos importan y cuáles no. Como sostiene Esposito:

El totalitarismo del siglo XX — sobre todo el nazi — señala el punto culminante de esta deriva tanatopolítica. La vida del pueblo alemán se convierte en el ídolo biopolítico al que se sacrifica la existencia de cualquier otro pueblo y, en particular, del pueblo judío, que, desde el interior parece contaminarla y debilitarla. Nunca como en este caso el dispositivo inmunitario marca una absoluta coincidencia entre protección y negación de la vida (Esposito, 2009, p. 131). 
Y es también este conflicto el que define los cuerpos que merecen y los que no merecen vivir, el que el cuerpo y la conciencia de José soportan en virtud de la múltiple clonación del personaje. Paramilitares, guerrilleros, institucionalidad y conciencia burguesa, todos al mismo tiempo y en el mismo espacio vital, encarnados en José deciden cuáles de sus múltiples cuerpos deben desaparecer. El cuerpo de José, como alegoría del cuerpo social, es escenario de negación y autodestrucción.

La cuestión de la identidad y de la comunidad se hace un interrogante abierto en Yo soy otro. En la película la pregunta por la identidad y su dimensión política deviene como una suerte de proceso deconstructivo. Se escarba en la noción de identidad para revelar qué guarda en su interior. Con sus excesos verbales, José se califica como un mutante. Y eso lo perturba: parece que puede ser cualquier cosa, pero sólo una de las réplicas de sí, no todas a la vez. La identidad individual naufraga no al reconocer que es múltiple y dispersa, sino al negar esa heterogeneidad y al intentar imponer como identidad un carácter monolítico y homogéneo. Igual sucede con el espacio intersubjetivo, social: su fracaso deviene de negar la política como heterogeneidad.

Lo político, sostiene Rancière, es el escenario donde se libra la batalla por la emancipación. Lo político, entonces, es el espacio de la diferencia y el disenso, de la política: "la política no es la dominación ni la gestión, sino que define una actividad excedentaria precisamente respecto a la lógica de la dominación y de la gestión. La política empieza con la existencia de sujetos que no son «nada», que son un exceso respecto al recuento de partes de la población” (Rancière, 2011, pp. 73-74). En términos de Adorno, lo universal no es la identidad. Lo universal es la no identidad. La comunidad política, lo común que haría lo político, como sostiene Rancière, es la igualdad que se halla en la diferencia: "Así es como podemos salir del debate sin salida entre universalidad e identidad. El único universal político es la igualdad” (Rancière, 2006, p. 19). Sin hacerlo explícito, a través de su yuxtaposición de conceptos encarnados en la multiplicación de José y de las acciones de negación y de autoeliminación que el personaje ejecuta Yo soy otro pone en escena la negación de esta forma de entender la política.

\section{A modo de conclusión}

No obstante lo anterior, la película no se carga de buenas intenciones. El filme no propone una reconciliación franciscana entre las fuerzas que hay en conflicto. Desvela la aporía en la cual se encuentra la sociedad. La película muestra la ausencia de sentido de este enfrentamiento, la operación suicida de la racionalidad que organiza estas fuerzas y la intersubjetividad dualista y maniquea que ellas han configurado. En este sentido, Yo soy otro escenifica a lo largo de su desarrollo el contenido de lo que he llamado una de sus premisas

argumentativas: en el mundo globalizado la violencia política, en lo local y en lo global, adquiere tonos de fundamentalismo. Esto es, como sostiene Richard 
Bernstein, "Hoy, después del 11 de septiembre, somos testigos de un choque de mentalidades. Y este choque trasciende la moral, la política y la religión. Se manifiesta en todas las áreas de la experiencia humana” (Bernstein, 2006, p. 90). De manera similar a como ocurre en la dialéctica de Adorno, la película aboga por la primacía del objeto, es decir, de la singularidad y de su derecho a no hacer parte de y a no dejarse identificar con ningún absoluto, sea éste cual sea.

Es razonable que de Yo soy otro hayan reprochado la frialdad de sus caracterizaciones y la ausencia en los espectadores de sentimientos de solidaridad o empatía con su personaje ${ }^{3}$. Pero la película, en mi opinión, no busca generar pasiones en los espectadores. Su protagonista no encarna sentimientos sino ideas. Como el ensayo, antes que a la pasión lo que el filme busca es incitar al pensamiento. Problemático, con todo, sí encuentro el exceso de palabras del protagonista y la redundancia innecesaria de José que a veces quiere explicar lo que dicen las imágenes.
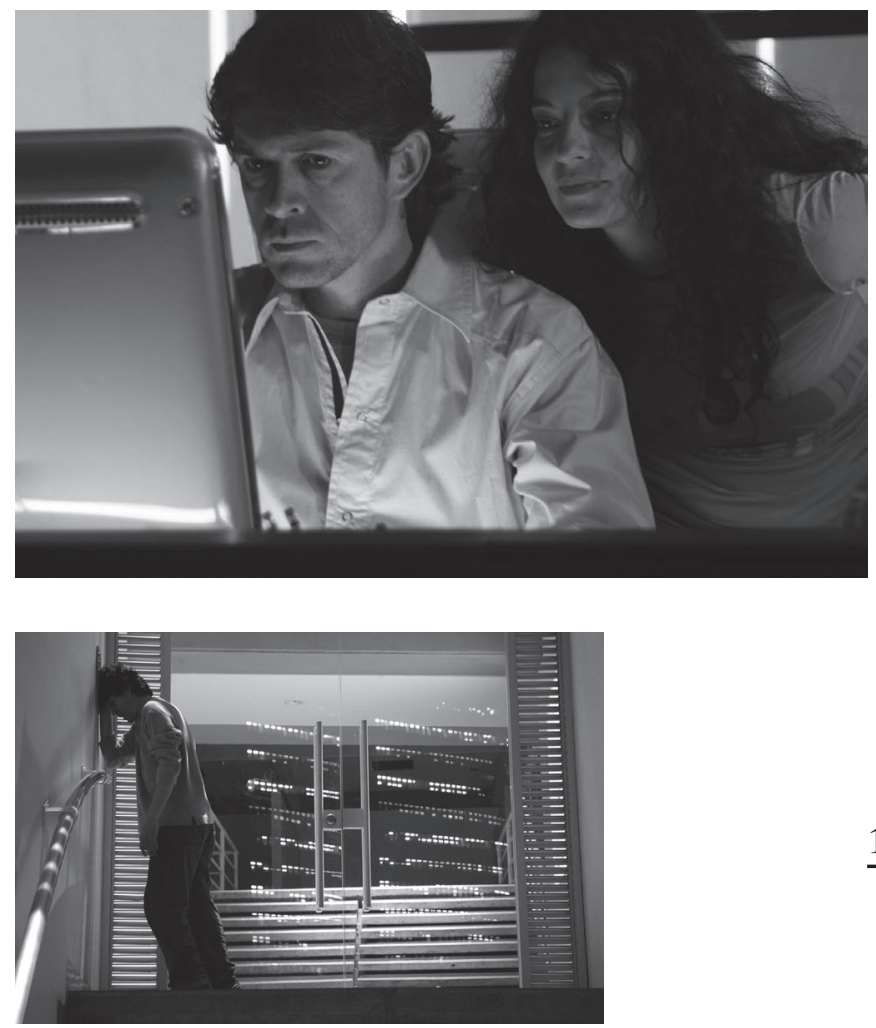

La enfermedad sin cura - pues para no cerrar la dialéctica al final vuelve a manifestarse en José-, su propagación viral y la autodestrucción consecuente le dan a la película un fuerte acento de distopía. Sin embargo, si invertimos la óptica creo que podríamos ver las cosas de otro modo. Yo soy otro no aboga por una síntesis o reconciliación entre las partes. La película, quedó dicho, desvela la opresión de unas formas de poder y de sus ideologías sobre los individuos. En medio de la barbarie generalizada que enmohece la historia del país y que desde todos los lados canta el bien y la solución para todos los males, la película hace suyo este precepto del pensamiento de Adorno: "La situación histórica hace que la filosofía tenga su verdadero interés allí precisamente donde Hegel, de acuerdo con la tradición, proclamó su indiferencia en lo carente de concepto, en lo particular y especial, eso que desde Platón fue despachado como perecedero y sin importancia" (1975, p. 16). En esa medida, Yo soy otro guarda un llamado a la toma de distancia del individuo con respecto a las formas de poder y a la afirmación de su singularidad y de su diferencia en relación con esas formas. En el fondo, la distopía cinematográfica deviene utopía social. Como escribió Adorno, "La utopía del conocimiento sería penetrar con conceptos lo que no es conceptual sin acomodar esto a aquéllos” (1975, p. 18). 


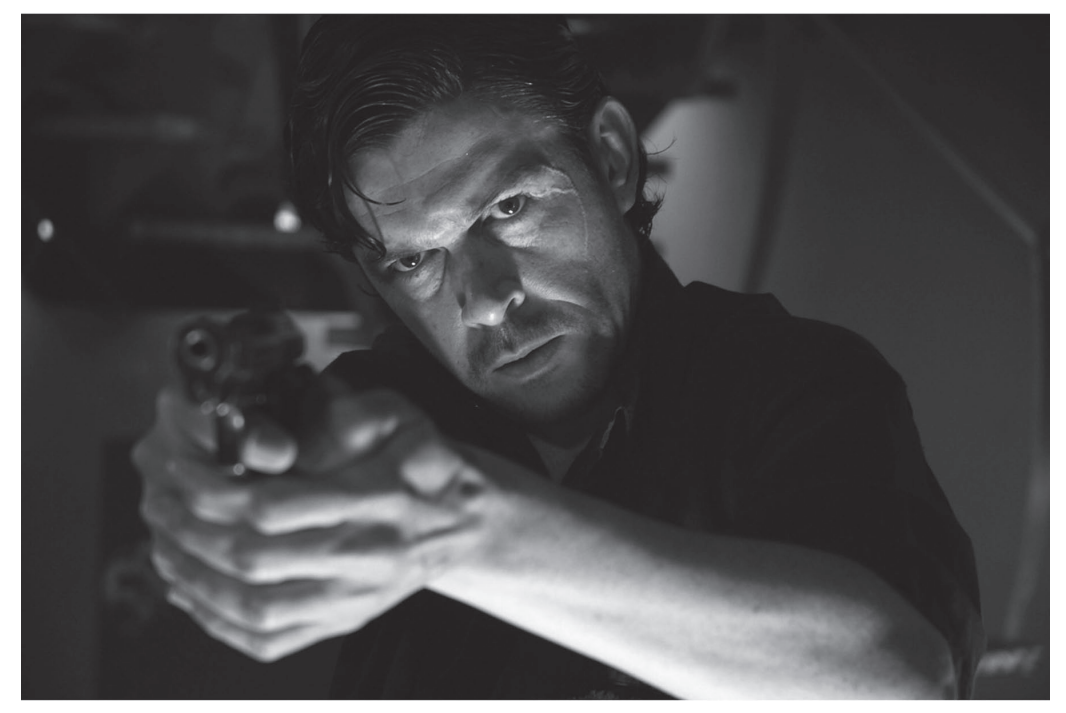

\section{Notas}

${ }^{1}$ Este artículo tiene origen en el proyecto de investigación "El conflicto armado colombiano en largometrajes de ficción. Un estudio sobre el cine en Colombia entre 1998-2012”. El proyecto no ha sido registrado ni vinculado formalmente a alguna institución y se ha desarrollado hasta ahora con recursos propios. Una versión más corta del texto fue presentada como ponencia en el II Congreso Internacional de Teoría Crítica realizado en la Universidad de Antioquia en 2013.

${ }^{2}$ Menciono, por ejemplo, a Silvia Schwarrzböck, Adorno y lo político. Buenos Aires, Prometeo, 2008. O en nuestro medio a Onasis Ortega, La teoría crítica ante la política. Cali: Fundación filosofía y ciudad, 2008.

${ }^{3}$ Refiero, por ejemplo, parte de la crítica de Pedro Adrián Zuluaga: “Aunque Campo afirme que llegarle al gran público no era su interés, es importante permitirse pensar que muchas cosas fallaron en el tránsito del guión a la puesta en escena, así hayan sido deliberadas o respondan a la lógica de un filme de tesis: la construcción dramatúrgica es endeble, los personajes no despiertan solidaridad y las ideas son demasiado explícitas". http: / / pajareradelmedio.blogspot.com/2009/03/oscar. html. Consulta en agosto de 2013. 


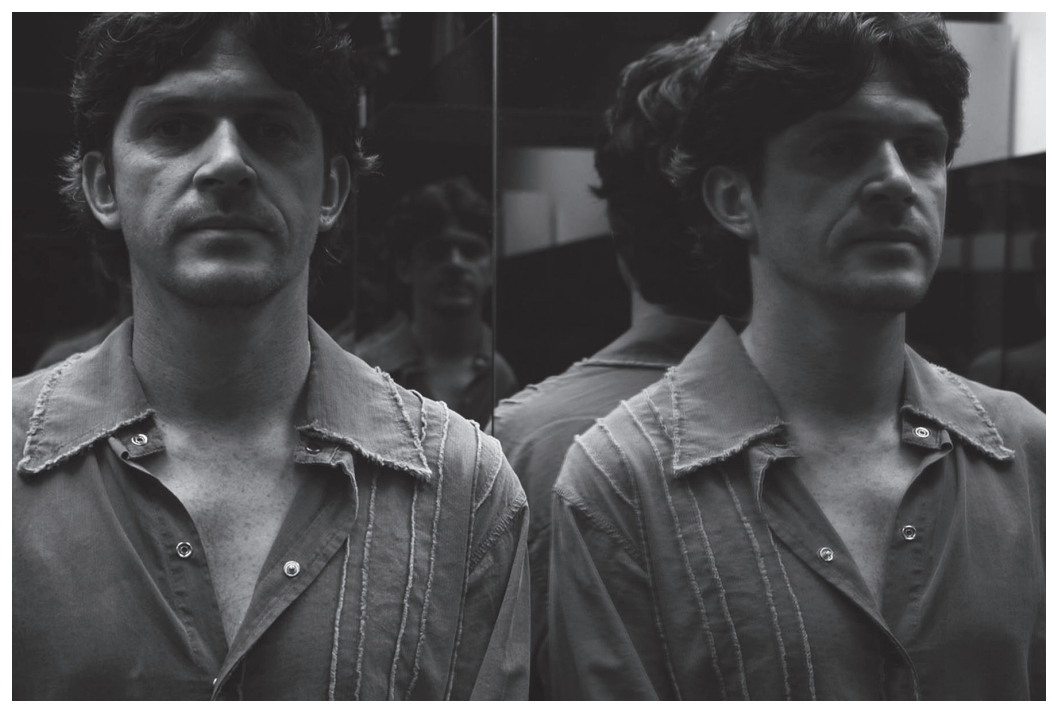

\section{Referencias}

Adorno, T. (1975). Dialéctica negativa. Madrid: Taurus.

Bernstein, R. (2006). El abuso del mal. Buenos Aires: Katz editores.

Esposito, R. (2009). Comunidad, inmunidad, biopolítica. Barcelona: Herder.

Horkheimer, M., \& Adorno, T. (1998). Dialéctica de la Ilustración. Madrid: Trotta.

Machado, A. (2012). El filme-ensayo. En J. L. (comp.), El medio es el diseño audiovisual (pp. 183-191). Manizales: Universidad de Caldas.

Rancière, J. (2006). Política, policía, democracia. Santiago de Chile: LOM Ediciones.

Rancière, J. (2011). El tiempo de la igualdad. Barcelona: Herder

\section{Filmografía}

Yo soy otro (Óscar Campo, 2006)

Recibido: noviembre 15 / Aprobado: noviembre 28 de 2014 